Oksana Rabczun

Kijów

\title{
Rodowa biblioteka Urbanowskich i Starzyńskich
}

W zbiorach Biblioteki Narodowej Ukrainy imienia W. I. Wernadskiego w Kijowie przechowywana jest znaczna liczba księgozbiorów, historia których jest związana się z dziejami i kulturą Polski. Pracując nad rozprawą naukową, związaną $z$ historyczno-księgoznawczymi badaniami rodowego księgozbioru znanych polskich przedstawicieli szlachty podolskiej Urbanowskich i Starzyńskich, wynikła potrzeba odszukania w zasobach archiwalnych i księgoznawczych informacji o właścicielach księgozbiorów, zbadania istniejących między nimi naukowych i kulturowych powiazzań, przeanalizowania ich bibliofilskich tradycji i upodobań.

Księgozbiorem Urbanowskich-Starzyńskich nikt $z$ badaczy ukraińskich dotąd się nie interesowal, chociaż dobór i tematyka zachowanych ksiązek jest nadzwyczaj ciekawa. Pochodzą $z$ okresu od początku XVI do początku XX stulecia. Znajdują się wśród nich wydania z: Bazylei, Krakowa, Warszawy, Lyonu, Rzymu, Wenecji, Lwowa, Berdyczowa, Kijowa, Moskwy, Sankt Petersburga. Tematyka księgozbioru jest równie szeroka: historia Polski i innych krajów, literatura teologiczna, geografia, literaturoznawstwo, językoznawstwo, słowniki, encyklopedie. Księgozbiór zawdzięcza swoją nazwę „Biblioteka Zahiniecka” miejscu gromadzenia i przechowywania: wsi Zahińce w powiecie latyczowskim, dzisiejszego obwodu chmielnickiego (Ukraina) ${ }^{1}$.

\footnotetext{
${ }^{1} \mathrm{~W}$ przygotowaniu niniejszego artykulu wykorzystane zostały następujące materiały archiwalne: [1.] Архів НБУВ, опис I, справа 2, s. 3; [2.] Архів НБУБ, опис I, справа 33, протоколи № 170, 181, 184, 185, 187; [3.] IP HBУB, ф. 1, № 121, 98s.; [4.] IP НБУВ, Ф. 1, № 1066, 134s. Skorzystano także $\mathrm{z}$ następujacej literatury: [5.] Chwalewik E., Zbiory polskie archiwa, biblioteki, gabinety, galerie, muzea i inne zbiory pamiq̨tek przeszłości w Ojczýnie i na Obczyźnie, t. 1-2, Kraków 1926-1927; [6.] Dobrzański J., Z dziejów ruchu naukowego na Wotyniu w XIX w., „Nauka Polska”, 1934, s. 118-119; [7.] Dudin-KarwieckiJ., Wędrówka od źródel do ujścia Horynia, Kraków 1891, s. 134-135; [8.] „Horodec”, w: Stownik geograficzny Królestwa Polskiego i innych ziem slowiańskich, t. 3, Warszawa 1882, s. 151; [9.] Epsztein T., Życie intelektualne i kulturalne dworu ziemiańskiego na Wotyniu, Podolu i Ukrainie $w$ drugiej potowie XIX wieku, w: Dwór polski w XIX wieku. Zjawisko historyczne i kulturowe, Warszawa 1998, s. 185-202; [10.] Kraszewski J. I., Biblioteka Horodecka, „Tygodnik Petersburski”, 1836, nr 2; [11.] Kraszewski J. I., Ksiqzka jubileuszo$w a$, Warszawa, 1880, s. 123; [12.] Kraszewski J. I., Wędrówki literackie, fantastyczne $i$ historyczne, t. 1 , Wilno 1839, s. 4896; [13.] Kraszewski J. I., Wspomnienia z Polesia, Wotynia i Litwy, t. 1, Wilno 1840; [14.] Małachowski P., Zbiór nazwisk szlachty, t. 2, tuck 1790; [15.] Maleczyńska K., Zasady doboru hasel z terenu Dolnego Ślquska do „Informatora o polskich ksiegozbiorach historycznych...", w: Symposia bibliologica. Warszawa 1995, s. 49-53; [16.] Polski Stownik Biograficzny, z. 175, Warszawa-Kraków 2004, s. 453-455; [17.] Radziszewski F., Wiadomość historyczno-statystyczna o znakomitych bibliotekach i archiwach publicz-
} 
Rodowym księgozbiorem Urbanowskich i Starzyńskich jeszcze w połowie XIX wieku interesował się znany polski pisarz, literaturoznawca i działacz spoleczny Józef Ignacy Kraszewski. Wspomina o niej w niektórych swoich utworach. Polscy badacze wymieniają $w$ swoich pracach kolejnych wlaścicieli Biblioteki Zahinieckiej: Antoniego Urbanowskiego i Bolesława Starzyńskiego oraz wspominają o samym księgozbiorze. W opracowaniach ukraińskich, jak dotąd, żadnych wiadomości odnaleźć się nie udało.

Głównym moim celem, w trakcie realizacji programu stypendialnego rządu polskiego dla młodych naukowców w Polsce, jest zebranie materiałów o posiadaczach księgozbioru i ich rodach, ewentualnych drogach nabywania, a następnie rozproszenia zbioru (dary, kupno, spadek itd.), zapoznania się z historią książki polskiej, jej wydawaniem i rozpowszechnianiem w Polsce glównie w XIX w., oraz opracowanie odnalezionych materiałów w celu ich wykorzystania w pracy doktorskiej. Podstawowe prace planuję przeprowadzić w następujących instytucjach: Bibliotece Narodowej, Bibliotece Uniwersyteckiej w Warszawie, Muzeum Narodowym w Warszawie, Archiwum Głównym Akt Dawnych, Bibliotece Jagiellońskiej, Bibliotece Instytutu Badań Literackich Polskiej Akademii Nauk, Bibliotece Zakładu Narodowego im. Ossolińskich we Wrocławiu.

Opracowanie niniejszego tematu pomoże uzupełnić i poszerzyć wiedzę o prywatnych bibliotekach szlachty polskiej na ziemiach ukraińskich (w szczególności na Wołyniu i Podolu). Efektem mojej pracy doktorskiej będzie poszerzenie wiedzy o Bibliotece Zahinieckiej, odtworzenie jej układu i organizacji zborów, a następnie wydrukowanie pelnego katalogu zachowanego księgozbioru. W wyniku tych prac uzupełnimy wiadomości o prywatnych bibliotekach, przechowywanych w zasobach ukraińskiej Biblioteki Narodowej.

Historia tej biblioteki sięga końca XVIII wieku. Wtedy to podkomorzy wielki koronny Wincenty Potocki, przymuszony dhugami, sprzedał swe obszerne dobra Niemirów na Podolu Szczęsnemu Potockiemu, który nabyl je dla swego syna Szczęsnego; wraz z pałacem zakupił też bogate zbiory obrazów, numizmatów oraz bibliotekę. Jednak nie pozostały one długo w rękach młodego Potockiego, który umarł w 1810 r., a dobra niemirowskie po raz kolejny, wraz z bogatymi zbio-

nych $i$ prywatnych tak niegdyś bytych jak $i$ obecnie istniejących $w$ krajach dawnq Polskę składajqcych..., Kraków 1875; [18.] Reychman K., Biblioteka Zahiniecka Starzynskich i jej losy, „Szpargały”, 1934, s. 53-54; [19.] „Starzyński Bolesław”, w: Stownik pracowników książki polskiej, Warszawa-Lodź 1972, s. 851; [20.] Starzyński Bolestaw, „Tygodnik Ilustrowany”, 1876, nr 22, cz. 1, s. 340-342; [21.] „Urbanowski Antoni” w: Stownik pracowników ksiażki polskiej, Warszawa-łódź 1972, s. 927-928; [22.] Wisłocki W., Biblioteka hr. Starzyńskich w Horodcu nad Horyniem - pow. tucki na Wotyniu, „Przewodnik Bibliograficzny”, 1885, nr 8, z. 10, s. 207; [23.] „Zahińce” w: Stownik geograficzny Królestwa Polskiego i innych krajów stowiańskich, t. 14, Warszawa 1895, s. 280; [24.] Дубровіна Л.А., Онищенко О.С., Історія Національної бібліотеки Украйни ім. В.І.Вернадського 1918-1941, Київ, НБУВ, 1998; [25.] Зданевич Б., Каталог інкунабул, Київ 1974; [26.] Каталог палеотипів з фондів НБУВ НАНУ, укладач М.А. Шамрай за участю Б. В. Грановського та І. Б.Торбакова, Київ 1995: [27.] Лісевич І. Т., Історичні зошити. Духовно спраглі (духовне життя польської національної меншини на Наданіпрянській Україні в 18641917 рр.), Київ 1997; [28.] Рабчун О., Загінецька бібліотека Урбановських-Стажинських: до проблем реконструкцї, „Наукові праці НБУВ”, 13, Київ 2004, s. 330-340; [29.] Труды Подольского историко статистического комитета, 9, Кам.-Подольский 1901, s. 519. 
rami, zostały sprzedane w drodze licytacji przez licznych wierzycieli zmarłego wlaściciela.

Niemirów wraz z częścią zbiorów nabył brat Szczęsnego, Bolesław Potocki; pozostała część kolekcji uległa rozproszeniu. Większą część biblioteki niemirowskiej i zbiory numizmatyczne po Wincentym Potockim kupil bogaty obywatel z Podola, Krzysztof Urbanowski, właściciel dóbr Rachny Lasowe w powiecie jampolskim. Urbanowski przewiózł nabytą kolekcję do swego majątku, a ponieważ sam byl zamiłowanym zbieraczem książek i numizmatów do końca życia uzupełniał ją dalszymi nabytkami. Umierając okolo 1830 r. podzielil swe zbiory testamentem między brata Antoniego i wnuka Edwarda Starzyńskiego. Ten ostatni, pragnąc widocznie aby zbiory pozostały w jednym ręku, ofiarowal Antoniemu Urbanowskiemu wybór stu obrazów, numizmaty wraz z odpowiednimi szafami (nabytymi podobno przez Wincentego Potockiego po królu Stanisławie Leszczyńskim) i najlepsze dzieła $z$ biblioteki pozostałej po Krzysztofie Urbanowskim [5].

Antoni Urbanowski (ok. 1770-1842) przewiózł wszystkie odziedziczone zbiory do swego majątku Horodziec w powiecie łuckim na Wołyniu. Musial sam być zamilowanym zbieraczem, gdyż posiadał już w Horodcu zbiory numizmatyczne, galerię obrazów oraz cenną bibliotekę, jedną z bogatszych na Wołyniu, do której włączono te ż księgozbiór Teodora Urbanowskiego $z$ Cepcewicz na Polesiu wołyńskim.

W roku 1835 biblioteka wraz ze zbiorami niemirowskimi liczyła około 13000 tomów, korzystali z niej m.in. Adam Jocher i Józef Ignacy Kraszewski, który bywał też pośrednikiem przy zakupach książkowych, sporządzil katalog zbiorów Antoniego Urbanowskiego w języku francuskim (niedrukowany; znajduje się w Instytucie Rękopisów NBUW w Kijowie) i opisal bibliotekę [21]:

„...na lewym brzegu rzeki, widzimy miasteczko Horodziec, mające ze Stepaniem i okolicznymi wsiami historyczną przeszłość, którą powtarzać uważam za rzecz zbyteczną. W pierwszych latach bieżącego stulecia, Horodziec znany był $z$ pięknego pałacu i cennych artystycznych zbiorów, nagromadzonych tu chwilowo przez miejscowego dziedzica Krzysztofa Urbanowskiego, a później brata jego Antoniego. Były tu dwie obszerne mozaikowe sale z pięknymi gibsurami, gzymsami i ornamentami sztukateryjnymi, wedle mody wówczas panującej. Obszerny ogród spacerowy, umiejętnie zarysowany, w którym sztuka zastąpiła piękność skąpej natury poleskiej; dziś zupełnie dziko zarasta, choć porządne oparkanienie broni go od pustoszenia przez okolicznych włościan. Piękny i cenny zbiór obrazów, pomiędzy którymi pamiętny byl oryginalny Guido Reni, cenna numizmatyka w porządnych szafach ułożona, a nabyta w Niemirowie po Wincentym Potockim, a szczególnie bogata biblioteka, zawierająca ciekawe manuskrypty, kilka pięknych Aldów-Elzewirów, wiele szacownych dzieł polskich, $z$ których wspomnieć należy oryginalny statut Łaskiego 1500 r. [sic!], rzadki zbiór Biblii, jak na przykład Pawła Seklucyana z 1556 r., Wujka z 1599 r. Oto są rzeczywiste powody, dla których należy się sympatyczne i zasłużone wspomnienie o tym poleskim nadhoryniowym miasteczku, a bardziej jeszcze o jego światłym 
właścicielu, którym potrafił w czasach, kiedy się rzadko jeszcze oddawano bibliografii i poważnej nauce, zebrać cenny księgozbiór, przechodzący jak powiadają liczbę 20000 tomów. Zbiory te w zupełnym komplecie znajdowały się w Horodcu niedługo, bo tylko od 1818 do 1852 roku; później w większej części przeniesione zostały na Podole i umieszczone w Rachnach i sąsiednich Zahińcach" [17].

Księgozbiór składał się głównie z poloników: zawierał opracowania i źródła historyczne, pierwodruki z XVI wieku, kilka cennych Biblii, wiele elzewirów i aldynów [12], broszury z XVIII wieku, literaturę dramatyczną (od komedii rybaltowskich po dzieła Aleksandra Fredry), zbiór klasyków greckich i rzymskich, dzieła $z$ zakresu botaniki, krajoznawstwa, sztuki, numizmatyki. Były tam również cenne rękopisy $z$ XVI wieku $z$ miniaturami ora $z$ wiele dzieł $z$ autografami. Po śmierci Antoniego Urbanowskiego w 1842 r. zbiory przeszły na własność wnuka Edwarda Starzyńskiego $z$ Zahiniec [5].

Żonaty $z$ Izabellą Mostowska, córką Tadeusza, 1-voto Aleksandrową Potocką, przebywal stale w Dreźnie, dokąd też przewiózl zbiór numizmatyczny i część galerii obrazów. Biblioteka pozostała w Horodcu do 1862 roku (w niektórych źródłach do 1863 lub nawet 1868), gdy po śmierci Edwarda Starzyńskiego syn jego Bolesław [13], przewiózł ją do rodzinnych Zahiniec (pow. latyczowski) i połączył $\mathrm{z}$ resztkami biblioteki $z$ Rachen Lasowych i wlasnym księgozbiorem.

Bolesław Starzyński (1834-1913), ziemianin, malarz, znany artysta, rzeźbiarz i złotnik, byl także zbieraczem książek. Dla odziedziczonej po ojcu biblioteki wybudowal w Zahińcach osobną salę, wysoką na dwa piętra i polączoną galeryjka. Uzupełnial księgozbiór głównie w zakresie historii sztuki. W 1896 Biblioteka Zahiniecka liczyła 16000 tomów i posiadała własny ekslibris [27, 29]. W 1913 roku spadkobiercy Starzyńskiego sprzedali majątek wraz z biblioteką Marii Branickiej, która nabyła ją dla swego wnuka Karola Radziwiłła. W 1917 roku Zahińce uległy zniszczeniu, a zbiory zostały przewiezione do Kijowa. Większość została włączona do Ogólnokrajowej Biblioteki Ukrainy i do biblioteki w Muzeum Tereszczenki; część uległa rozproszeniu [19].

Według różnych źródel Biblioteka w Zahińcach liczyła od 16000 do 20000 książek, w tym wiele starych druków, wśród nich inkunabuły; znajdowały się tam także rękopisy iluminowane, różne archiwalia, ryciny i mapy. Niektóre tomy Bolesław Starzyński własnoręcznie oprawiał, zamieszczając na nich superekslibris $z$ herbem Doliwa; oznaczone były nim również niektóre inne egzemplarze [22].

W Zahińcach Starzyński urządził swoją pracownię [20]. Z jego twórczości malarskiej znane są tylko dwa obrazy olejne: pochodzące jeszcze $z$ roku 1852 plótno przedstawiające konia przy wodopoju (Muzeum Narodowe w Warszawie), oraz niedatowana i niesygnowana podobizna króla Stefana Batorego (Zbiory Zamku Królewskiego na Wawelu).

Bolesław Starzyński prowadził badania naukowe nad uzbrojeniem rycerstwa polskiego, herbami i genealogia, lowiectwem oraz myślistwem. Prawdopodobnie w ostatniej ćwierci XIX wieku poświęcił się głównie tym zagadnieniom, odchodząc stopniowo od twórczości artystycznej. Rezultatem wieloletnich starań 
i prac stal się katalog dawnego uzbrojenia (obecnie w Bibliotece Jagiellońskiej), składający się $z$ siedmiu tomów, zawierających opisy oraz wykonane głównie przez Starzyńskiego plansze, rysowane piórkiem i barwione farbami wodnymi. Spis zawartości większej części tego dzieła (Katalog pięciu tomów broni zaczepnej $i$ odpornej $w$ Polsce) opublikował we Lwowie w roku 1894.

Przez około dwadzieścia lat Starzyński pracował nad herbarzem. Dzieło to obecnie znajduje się w Bibliotece Jagiellońskiej zachowane w szesnastu tomach (tom siedemnasty, zawierający genealogię rodzinna, jest w zbiorach prywatnych we Francji). Autor zamieścił w nim prawie 1500 rysunków herbów polskich, litewskich, ruskich i ormiańskich, a także utytułowanych rodów $\mathrm{z}$ różnych państw europejskich, uzupełniając je wykazami koligacji, głównie $z$ XIX wieku; przedstawil tu także herby miast i cechów, gmerki lwowskich mieszczan, znaki kamieniarzy itd.

Z Zahiniec wyjeżdżal często do Francji, gdzie spędzał wiele czasu w Nicei (utrzymywal tu druga pracownię) i w Paryżu. Prowadził wystawny tryb życia i uchodzil za kosmopolitę. W latach 1899-1904 ofiarował Bibliotece Jagiellońskiej mszal, herbarz, katalog broni i albumy fotograficzne wraz z sekretarzykiem własnego projektu. 15 lipca 1912 roku, po śmierci drugiego syna, sporządzil testament, prawdopodobnie zapisując Zahińce $z$ biblioteką jedynej córce.

Starzyński używal tytułu hrabiowskiego, co uzasadnił w swym herbarzu następującą informacją: „za cesarza Pawła na zasadzie przyznania deputacji wywodowej Gubernii Podolskiej potwierdzono tytuł Józefowi, chorążemu latyczowskiemu i bratu Ludwikowi. Akt urzędowy zostal podany do Komisji Legitymacyjnej Polskiej w Kamieńcu w 1851 i 1853 roku”. Jednakże Spisok dvorian... $z$ roku 1913 zawiera tylko informację o wpisaniu do księgi szlachty w 1840 roku Edwarda Starzyńskiego z synem Bolesławem, a także w 1879 r. dzieci Bolesława: Róży Marianny, Witolda i Stanisława. Na mocy ukazu rosyjskiego z 5 maja 1911 roku rodzinie Starzyńskich przyznano prawo posługiwania się również formą nazwiska Starzeński (rodzina o tym nazwisku posiadała tytuł hrabiowski). Sam Bolesław Starzyński podpisując się jako „hrabia” używał jednak wyłącznie nazwiska Starzyński [16].

Starzyński oprócz Zahiniec posiadał m.in. miasteczko Zahnitków, gdzie od 1876 r. utrzymywal cukrownię (czynną do 1895 r.), wraz z dobrami: Studenica (nabyte w 1858 r.), Podejma, Podejmica i Waladynka.

Starzyński zmarł w Paryżu 26 stycznia 1917; pochowany zostal obok ojca Edwarda oraz pierwszej żony i synów na cmentarzu Père Lachaise.

Pierwszą żoną Bolesława Starzyńskiego była Helena de Weyrauch (zm. 27 X 1904), z którą mial córkę Różę Marię (Mariannę, ur. 1861), zamężną od 5 V 1883 za Stefanem Szembekiem, oraz synów: Witolda (1864-1906) i Stanisława (1872-1912). $Z$ drugiego małżeństwa $z$ Marguerittą Hortense Dubois (zm. przed lipcem 1930) dzieci nie pozostawil.

Róża Maria już w roku 1913 sprzedała klucz zahiniecki siostrzenicy matki Starzyńskiego, Marii z Sapiehów Władysławowej Branickiej, która nabyła je dla wnuka Karola Radziwilla [5]. 
Losy artystycznych zbiorów Starzyńskiego nie są znane. Dzieła sztuki przeznaczone dla Zamku Królewskiego na Wawelu (druga żona Starzyńskiego zajmowała się po jego śmierci tą darowizną) były początkowo przechowywane we Francji, potem trafily do ambasady RP w Paryżu, niektóre $z$ nich pozostały w ambasadzie, a inne w 1930 roku przewieziono na Wawel. W zbiorach wawelskich zatrzymano tylko rzeźbę husarza na koniu i tzw. tarczę Sobieskiego oraz kilka sztuk broni; pozostale przedmioty przeznaczono na wymianę lub na sprzedaz.

Dwór ziemiański był często ośrodkiem życia kulturalnego i naukowego, miejscem gdzie kształcono młode pokolenia, rozwijano własne zainteresowania i pasje, czy taż gromadzono różnorodne zbiory. Widać to dobrze na przykładzie siedzib polskiego ziemiaństwa na Wołyniu, Podolu i Ukrainie (gubernia wołyńska, podolska i kijowska w Rosji) [9].

W bibliotekach ziemiańskich bardzo ważną pozycję zajmowała literatura piękna, beletrystyka oraz ksiażki historyczne, ale o charakterze popularnym [15]. Na pierwszym miejscu były dzieła polskich klasyków, szczególnie XIX stulecia: Mickiewicz, Słowacki i Krasiński. Czytano także Kraszewskiego, Korzeniowskiego, Rzewuskiego, Kaczkowskiego, Syrokomlę, Zaleskiego itd. Z książkami polskimi silnie konkurowały francuskie. W niektórych domach te ostatnie dominowały. W mniejszym wyborze spotykano książki niemieckie. W języku niemieckim sprowadzano głównie literaturę fachową rolniczą i techniczną. Książki rosyjskie kupowano przede wszystkim dla młodzieży męskiej, która byla zmuszona dobrze opanować język rosyjski. Dziewczęta rosyjskiego się nie uczyły, stąd literatura rosyjska w oryginale nie zawsze była obecna w domach polskich. Od końca XIX wieku rośnie zainteresowanie literaturą angielską, ale książki $\mathrm{w}$ języku angielskim stanowily niewielki margines pozostałych sprowadzanych na Kresy, gdyż nadal niewielki tylko procent ziemiaństwa znal angielski [7].

Zainteresowania naukowe ziemiaństwa przeważnie skierowane były w stronę szeroko rozumianych nauk humanistycznych, a wśród nich pierwsze miejsce zajmowały nauki historyczne. Pasjonowano się dziejami kraju, regionu i okolic, ale także historia Europy, rodzin panujących, historią kultury, cywilizacji, historią polityczną itd. W szeregu zainteresowań historycznych nie mogło zabraknąć badań nad przeszłością własnej rodziny.

Dwory ziemiańskie kryły w sobie nieraz bardzo cenne zbiory i kolekcje sztuki, biblioteczne, archiwalne, mebli, porcelany itd. [6]. Kolekcjonerstwo należało bowiem także do dość typowych pasji ziemiaństwa. Zbiory ziemiańskie miały inny charakter niż kolekcje w dzisiejszym tego słowa znaczeniu. Cechą najbardziej typową byla ich duża różnorodność i przypadkowość, będąca konsekwencją zmieniających się zainteresowań twórcy, przemijającej mody, procesów dziedziczenia i nawarstwiania się zbiorów za życia kilku pokoleń. Bardzo rzadko zasoby dworów ograniczały się do jednego typu przedmiotów. Interesowano się przeważnie kilkoma dziedzinami naraz. Amator malarstwa miał także kolekcje sztychów i porcelany, a na dodatek zbieral rodzinne dokumenty i kompletował bibliotekę, a w spadku po ojcu miał zbiorek pasów kontuszowych. Do wyjątków 
nalezały kolekcje tworzone według ściśle określonych zainteresowań właściciela, zbiory specjalistyczne, nastawione na konkretne przedmioty, dziedzinę sztuki, epokę, wreszcie wylamujące się swoim charakterem i formą $z$ panującej mody. Ale nawet i w tych przypadkach rodzinne kolekcje zawierały zbiory typowe dla większości siedzib, a więc biblioteki, archiwa, galerie, porcelanę i fajanse, srebra, meble itd.

Po roku 1913, kiedy biblioteka stała się własnością Branickich, żadnych wiadomości o niej nie mamy. W $1921 \mathrm{r}$. rozpoczęła się na Ukrainie konfiskata księgozbiorów i włączanie wszystkich bibliotek do Ogólnokrajowej Biblioteki Ukrainy [1, 2, 24]. W ten sposób Biblioteka Zahiniecka trafiła do Kijowa, gdzie zbiory jej uległy rozdzieleniu pomiędzy różne działy Centralnej Naukowej Bibliotekj Ukrainy.

W latach siedemdziesiątych XX wieku odnotowano w zbiorach CNBU siedem inkunabułów [25] pochodzących z Biblioteki Zahinieckiej, a w latach dziewięćdziesiątych 38 paleotypów [26].

Zachowane do dzisiaj zbiory Biblioteki Zahinieckiej zawierają książki o różnorodnej tematyce. Przykładowo można wymienić:

Euripidis tragoediae septendecim, ex quib[us] quaedam habent commentaria. IVol. 2: Graece]. Venetiis 1503.

Homer: Ilias hoc est, De rebus ad Troiam gestis descriptio. Basilae 1511.

Statuta Sinodalia et p/ro/uincialia etc. Nurembergae 1512.

Krantz, Albert: Wandalia in qua de Wandalorum populis et eorum patrio solo ac in Italiam, Galliam, Hispanias, Aphricam et Dalmatiam migratione, et de eorum regibus ac bellis domi forisque gestis. Coloniae Agrippinae 1519.

Ovidius Naso, Publius: Epistole heroides Publii Ovidii Nasonis diligenti castigatione exculte... Lugduni, 1529.

Vergilius Maro, Publius: Vergilius [Bucolica, Georgica, Aeneis Nicolai Erythraei]. Parisiis 1538.

Ptolemaeus, Claudius: Clavdii Ptolemai Pelvsiensis Alexandrini Omnia, Qvae Extant, Opera. Geographia excepta, quam seorsim quoque hac forma impressimus... Basileae 1541.

Sabinus, Georg: Georgii Sabini Brandeburgensis Pö̈mata. Argentorati 1544.

Dubowicz, Jan: Hierarchia abo o Zwierzchnosci w Cerkwi Bozey. Lwów 1644.

Borkowski, Modest: Complement ozdoby starozytney Pilawie przez Jáśnie Wielmożnego Jogo Mośći Pána Mikolaia z Potoka Potockiego... Lwów 1652.

Glinka, Franciszek: Zwierzyniec Iednorozcow [...] z Przydatkiem rożnych mow Seymowych, Listow, Pism y Discursow [...] tegoz Andrzeia Maximiliana Fredra [...]. Lwów 1670. 
Bratkowski, Daniel: Swiat po Częsci przeyrzany. Kraków 1697.

adl::

Bando: Bando przeciwko gorzatce y wszystkim iey naśladowcom. Supraśl 1720. adl:

Bieżanowski, Stanisław Józef: Lew przyiemny choćiasz ognisty, liliowym, do wieczney pámięcí związkiem zniewolony. [S.1.] 1676.

Wessel, Augustyn Adam: Morze miłosierdzia y Dobroci Bozey Pokazane grzesznikowi y grzesznicy... Lwów 1735.

Jabłonowski, Józef Aleksander: Heraldica To iest osada kleynotow rycerskich $y$ wiadomosc znakow herbownych dotąd $w$ Polszcze nieobiaśniona, praca y wynalazkiem... Lwów 1742.

Bobiński, Remigiusz: Meta nieodmienney intencji ná utwierdzenie bez terminu rodzićelskich pociech Jasnie Wielmoznego Jmści Pana Macieia Mycielskiego... Lwów, 1743.

Pikulski, Gaudenty: Ztość Żydowska przeciwko Bogu y bliźniemu prawdzie y sumnieniu na obiaśnienie Talmutystow Na dowód ich zaślepienia, y Religii dalekiey od prawa Boskiego przez Moyżesza danego. Lwów, 1758.

Kleczewski, Stanisław: Kalendarz seraficzny Zamykający w sobie Żywoty Wielebnych Stug Boskich Zakonu S. O. Franciszka Reformatow Polskich Osobliwa Swiq̨tobliwościq znamienitych. Lwów 1760

Cornaro, Luigi; Lessius, Leonardus: Nauka zdrowia, to iest, skuteczny sposób, którym się zdrowie dobre i życie a przytym zmystów, rozumu y pamięci catość aż do ostatniey starości dochować moze. Traktatów II. Lwów 1765.

Kollątaj Hugo: Uwagi nad Pismem, które wyszto w Warszawie, z Drukarni Dufourowskiej pod tytutem: Seweryna Rzewuskiego Hetmana Polnego koronnego o Sukcessyi Tronu w Polszcze rzecz krótka. Warszawa, 1790. adl:

Kollątaj Hugo: O ustanowieniu i upadku Konstytucyi Polskiey 3go Maia 1791.

Niemcewicz, Julian Ursyn: Kazimierz Wielki. Dramma we trzech aktach. Warszawa: 1792.

Niemcewicz, Julian Ursyn: Pisma różne wierszem i prozą. T. 1-2. Warszawa 18031805.

Krasicki, Ignacy: Dzieta poetyckie. T. 2-10. Warszawa 1804.

Niemcewicz, Julian Ursyn: Samolub, komedja $w 5$ aktach, wierszem. Warszawa 1814. Na zwrotniej stronie tytulu pieczatka u tekstem w języku ukrainskim: Бібліотека УАН Відділ польської літератури.

Krasicki, Ignacy: Bajki i przypowieści, tudzież Bajki nowe dla użytku młodzieży 
szkolnej. Wilno 1815.

Wolski, Jan: Fizyka stosownie do teraźniejszego stanu wiadomości krótko zebrana... Warszawa 1817.

Niemcewicz, Julian Ursyn: $O$ więzieniach publicznych, czyli domach pokuty. Warszawa 1818.

Krasicki, Ignacy: Kazania... Warszawa 1819.

Niemcewicz, Julian Ursyn: Dzieje panowania Zygmunta III, króla polskiego... T. 1-3. Warszawa 1819. Na stronie tytułowej pieczątka-ekslibris „Biblioteka Zahiniecka".

Niemcewicz, Julian Ursyn: Zbiór pamiętników historycznych o dawney Polszcze $z$ rekopismów, tudzież dziet $w$ rożnych językach ... T. 1-6. Warszawa, 1822.

Siarczyński, Franciszek: Mowa żatobna na śmierć S. O. ksiażęca Adama Kazimierza na Klewaniu i Zukowie Czartoryskiego. Lwów 1823.

Niemcewicz, Julian Ursyn: Jan z Tęczyna, powieść historyczna przez... T. 1-3. Warszawa 1825.

Mickiewicz, Adam: Sonety Adama Mickiewicza. Lwów 1827.

Krasicki, Ignacy: Myśli i zdania moralne i filozoficzne. Wilno 1828. Na ostatniej stronie pieczątka czerwona $z$ monogramem „F.S.”.

Krasicki, Ignacy: Dzieta. T. 1-10. Warszawa 1829.

Krasicki, Ignacy: Dzieta. T. 1-8. Warszawa 1830.

Parvez P.: Nowa grammatyka francuzka [François-Joseph-Michel] Noél'a i [Charles-Pierrel Chapsal'a. Warszawa 1835.

Zimorowicz, Bartłomiej: Historya miasta Lwowa, królestw Galicyi i Lodomeryi stolicy... Lwów 1835.

Muczkowski, Józef: Grammatyka języka polskiego. Kraków 1836.

Kołlątaj Hugo: Pamiętnik o stanie Duchowieństwa Katolickiego Polskiego i innych wyznań $w$ potowie XVIII wieku. Poznań 1840.

Schmidt, Friedrich August: Dzieje Królestwa Polskiego krótko lat porzqdkiem opisane. T. 1-2 Iprzekt.] przez J. Albertrandego. Lwów 1846.

Szajnocha, Karol: Szkice historyczne. T. 1-4. Lwów 1858.

Grabowski, Ambroży: Kraków i jego okolice. Kraków 1866.

Wincenty Kadłubek, Magistri Vincentii Chronicon Polonorum = Mistrza Wincentego Kronika Polska. Lwów 1872.

Polkowski, Ignacy: Żywot Mikotaja Kopernika. Gniezno 1873. 
Karwowski, Stanisław: Wiek XVI czyli Dzieje odkryć, politycznych przeobrażeń i reformacji. Poznań 1881.

Stadnicki, Kazimierz: Synowie Gedymina, wielkowładcy Litwy... Lwów 1881.

Węgierski, Tomasz Kajetan: Pisma wierszem i proza. Lwów 1882.

Starzyński, Stanisław: Sprawa języka państwowego w Austryi. Lwów 1884.

Według katalogów Biblioteki Zahinieckiej powinny być dwa egzemplarze książki „Starzyński, Bolesław: Katalog pięciu tomów broni zaczepnej i opornej w Polsce. Lwów 1894", ale dzisiaj nie udało się odszukać żadnego w NBUW.

Według katalogów $z$ lat 1870 i 1905 [3, 4] w Bibliotece Zahinieckiej powinny być następujące książki autorstwa J. I. Kraszewskiego:

1)

Rok ostatni panowania Zygmunta III. Wilno 1833.

Mistrz Twardowski. Powieść z podań gminnych. Wilno 1840.

Cale życie biedna. Powieść pierwsza. Wilno 1840.

Stańczykowa kronika od r. 1503 do 1508. Wilno 1841.

Ostatnia z Ksiazż̨t Stuckich. Wilno 1841.

Powieść sktadana J. I Kraszewskiego i Johna of Dycalp [pseud., Jankowski Placyd]. Wilno 1844.

Latarnia czarnoksięska. Obrazy naszych czasów Oddziat I-II. Warszawa 18431844.

Pod wtoskiem niebem. Fantazya. Lipsk 1845.

Pamiętniki nieznajomego. Warszawa 1846.

Czasy Zygmuntowskie. Powieść z r. 1572. Warszawa 1846.

Milion posagu. Powieść. Warszawa 1847.

Sfinx, powieść. Warszawa 1847.

Ostrożnie z ogniem. Powieść nowa. Lwów 1849.

Pan i szewc. Powieść. Wilno 1850.

Resztki życia. Powieść. 1858.

Staropolska mitość. Urywek Pamiętnika. Warszawa 1859.

Dola i niedola. Powieść z ostatnich lat XVIII wieku. Warszawa 1864.

Macocha, z podań XVIII w. Powieść. Warszawa 1873.

Boża opieka, powieść osnuta na podaniach XVIII wieku. Lwów 1873.

Powrót do gniazda. Powieść z podań XVI wieku. Warszawa 1874.

$Z$ siedmioletniëj, opowiadanie historyczne. Warszawa 1876.

Stara baśń. Powieść z IX wieku. T. 1-3. Kraków 1876.

Lubonie. Powieść $z$ X wieku. Kraków 1876.

Bracia zmartwychwstańcy : powieść z czasów Chrobrego. Kraków 1876.

Starosta Warszawski. Obrazy historyczne z XVIII wieku. Warszawa 1877.

Mastaw. Powieść z XI wieku. Kraków 1877.

Królewscy synowie. Powieść z czasów Wtadystawa Hermana i Krzywoustego.

Kraków 1877. 
Skrypt Fleminga. Powieść historyczna z czasów Augusta II. 1878.

Syn marnotrawny. Opowiadanie z końca XVIII wieku. 1878.

Stach z Konar. Powieść historyczna z czasów Kaźmierza Sprawiedliwego.

Kraków 1879.

2)

Tęczyńscy. Dramat historyczny w 5 aktach, proza. Wilno 1844.

Miód kasztelański. Komedya kontuszowa w 5 aktach prozq. Kijów 1860.

Ciepta wdówka. Komedya kontuszowa we trzech aktach wierszem. Poznań 1866.

Panie Kochanku. Anegdota dramatyczna. Poznań 1867.

Równy wojewodzie. Obraz dramatyczny z XVIII wieku, w5 aktach. Poznań 1868.

Radziwitt w gościnie. Anegdota dramatyczna. Lwów 1872.

3)

Poezye. T. 1-2. Wilno 1838.

Hymny boleści. Paryż 1857.

Wioska. Sielanka. Warszawa 1858.

4)

Wielki świat matego miasteczka. 1833.

Wędrówki literackie, fantastyczne i historyczne. Część I. Wilno 1839.

Poeta i świat. Powieść. Poznań 1839.

5)

Studya literackie. Wilno 1842.

Nowe studya literackie. Warszawa 1843.

6)

Wędrówki literackie, fantastyczne i historyczne. Część II. Wilno 1839.

Obrazy z życia i podroży. Wilno 1842.

Wspomnienia Odessy, Jedyssanu i Budżaku. Dziennik przejażdżki w roku 1843 od 22 Czerwca do 11 Września. Tom I. Wilno 1845.

Wieczory wotyńskie. Lwów 1859.

Wspomnienie Polesia, Wotynia i Litwy. 1861.

W NBUW zachowały się następujące tomy:

Kraszewski, Józef Ignacy: Improwizacye dla moich przyjaciót, ksiązeczka do zapalania fajek. Wilno 1834.

Kraszewski, Józef Ignacy: Poezye. T. 1-2. Wilno 1838.

Kraszewski, Józef Ignacy: Wilno od początków jego do roku 1750. T. 1. Wilno 1838.

Kraszewski, Józef Ignacy: Szkice obyczajowe i historyczne. T. 1-10. Wilno 18401841.

Z badań nad książką i księgozbiorami historycznymi, 3:2009 
Kraszewski, Józef Ignacy: Bracia zmartwychwstańcy: powieść z czasów Chrobrego. T. 1-3. Kraków 1876.

Kraszewski, Józef Ignacy: Lubonie. Powieść $z$ X wieku. Kraków 1876.

Kraszewski, Józef Ignacy: Stara baśń. Powieść z IX wieku. T. 1-3. Kraków 1876.

Kraszewski, Józef Ignacy: Boleszczyce: powieść z czasów Bolestawa Szczodrego. T. 1-2. Kraków 1877.

Kraszewski, Józef Ignacy: Masław. Powieść z XI wieku. T. 1-2. Kraków 1877.

Kraszewski, Józef Ignacy: Na bialskim zamku. Powieść historyczna z czasów Augusta III. T. 1-2. Kraków 1877.

Kraszewski, Józef Ignacy: Bratanki. Powieść z podania początku XVIII wieku. T. 2. Warszawa 1879.

Kraszewski, Józef Ignacy: Pod blachą. Powieść z końca XVIII wieku. T. 1-3. Warszawa 1881.

Kraszewski, Józef Ignacy: Rodzeństwo. Obrazek wspótczesny. T. 1-2. Kraków 1884 Na końcu książi wklejone nalepki introligatorskie o treści: „Richard Oesterrich. Drezden. Könnigl. Hof Buchbinder".

$Z$ innych autorów polskich mamy:

Trembecki, Stanisław: Poezye. T. 1. Warszawa 1819.

Mickiewicz, Adam: Poezye. T. 2. Wilno 1823.

Lelewel, Joachim: $O$ historii, jej rozgatęzieniu $i$ naukach zwiazek z nia majacych. Warszawa 1826.

Lelewel, Joachim: Edda to jest Księga religii dawnych Skandynawii mieszkańców. Wilno 1828.

Lelewel, Joachim: Poczqtkowe prawodawstwo polskie cywilne $i$ kryminalne do czasów Jagiellonskich. Warszawa 1828.

Trembecki, Stanisław: Dzieta poetyczne... T. 1-2. Wrocław 1828.

Lelewel, Joachim: Dzieje Polski... potocznym sposobem opowiedziat, do nich dwanaście krajobrazów skreślit. Warszawa 1829.

Fredro, Aleksander: Komedye. T. 3-5. Lwów, Stanisławów, Tarnów 1830.

Słowacki, Juliusz: Poezye. T. 2. Paryż 1832.

Lelewel, Joachim: Polska, dzieje i rzeczy jej rozpatrywane rozpatrywane przez... T. 1-3. Poznań 1858. Na stronie tytułowej pieczątka-ekslibris „blioteka Zahiniecka". 
Mickiewicz, Adam: Pisma. T. 3. Warszawa 1858.

Starzyńscy herbu „DOLIWA”: w polu błękitnym na szerokiej białej wstędze ukośnie $z$ prawej strony do dołu ku lewej ułożone trzy róże pełne, w równej odległości. Na helmie między dwoma trąbami trzy róże w prosto jedna nad drugą. Ten Herb nadany został Doliwom za czasów Leszka IV [14].

Bolesław Starzyński wykorzystał rodzinny herb w ekslibrisie swojej biblioteki. Zmianie uległa korona. Dookoła tarczy dodano pas [bandoliera?] z napisem: BIBLIOTEKA ZAHINIECKA.

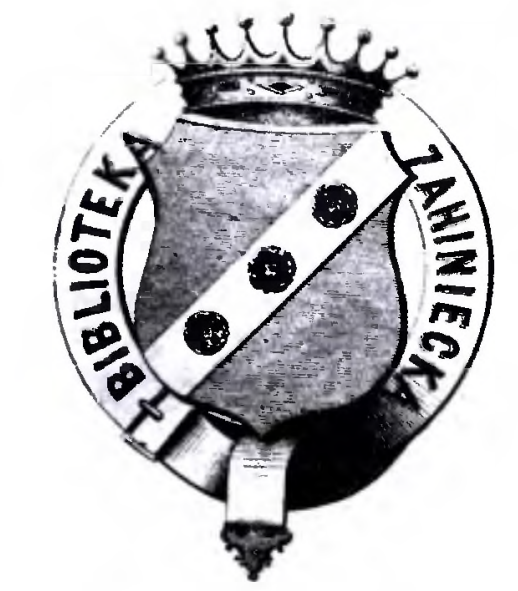

Ekslibris heraldyczny Biblioteki Zahinieckiej.

Oprawy książek są różne. Wiemy, że pewną liczbę opraw wykonał sam Bolesław Starzyński. Zrobione są ze skóry koloru brunatnego albo zielonego. Większość tych opraw nie znajduje podobnych w innych kolekcjach NBUW. Pierwotnie wydawało się, że są charakterystyczne tylko dla Biblioteki Zahinieckiej, ale w Warszawie spotyka się podobne oprawy na rękopisach, oprawionych w XIX wieku.

$\mathrm{Na}$ książkach $z$ Biblioteki Zahinieckiej występują ważne autografy, pośród nich dedykacje Józefa Ignacego Kraszewskiego i Stanisława Starzyńskiego (dla wlaścicieli biblioteki). Mamy też kilka zapisów ręką Bolesława Starzyńskiego w języku francuskim.

Z badań nad książką i księgozbiorami historycznymi, 3:2009 